\title{
Evaluation of a Modified Jejunoileal Bypass Technique (Lazzarotto and Souza Procedure): Causes of Reversal and Types of Possible Procedures
}

ISSN: 2637-7632

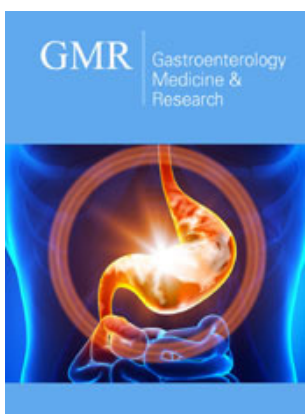

*Corresponding author: Sulaiman Almazeedi, Jaber Al-Ahmad Hospital, Kuwait

Submission: 海 July 15, 2020

Published: 漈August 10, 2020

Volume 5 - Issue 1

How to cite this article: Sulaiman Almazeedi. Evaluation of a Modified Jejunoileal Bypass Technique (Lazzarotto and Souza Procedure): Causes of Reversal and Types of Possible Procedures. Gastro Med Res. 5(1). GMR.000603. 2020.

DOI: 10.31031/GMR.2020.05.000603

Copyright@ Sulaiman Almazeedi, This article is distributed under the terms of the Creative Commons Attribution 4.0 International License, which permits unrestricted use and redistribution provided that the original author and source are credited.
Giorgio Baretta ${ }^{1}$, Hmoud Alrashidi ${ }^{1}$, Glauco afonso Morgenstern ${ }^{1}$, Maria Cambi $^{1}$, Arieli Baretta ${ }^{1}$, Sarah Al-Youha ${ }^{2}$, Sulaiman Almazeedi*2 and Loureiro Marcelo ${ }^{1}$

${ }^{1}$ Vita Batel Hospital, Curitiba, Parana, Brazil

${ }^{2}$ Jaber Al-Ahmad Hospital, Kuwait

\section{Introduction}

Obesity became a pandemic according to WHO in a world where more than one billion people are classified as overweight or obese [1]. It has been associated with many diseases including hypertension, diabetes mellitus, cardiovascular disease, stroke and cancer [2]. Many procedures have been developed in the past years, some of them were effective, while others caused major side effects and morbidity to patient. Jejunal-ileal bypass was introduced in 1950 's, however it did not reach its peak popularity due to the introduction of other modified procedures with better outcomes and less complications, such as sleeve gastrectomy and Roux-en-Y gastric bypass (RYGB) [3]. During the time the jejunal-ileal bypass was dominated by other more successful procedures, its side effect also began to become more apparent. Almost all patients who underwent this procedure had metabolic, mechanical and nutritional complications. Lazzarotto and Souza procedure is modified jejunoileal bypass in which a silastic ring is placed at the remnant jejunum to control the amount of food content reaching the bypassed small bowel. Although it has been shown to be effective is weight loss, it is associated with complications and yet is not approved by the Brazilian society of bariatric and metabolic surgery.

\section{Methods}

This is a retrospective evaluation of data collected from two hospitals located in Curitiba, Parana state, 21 patients underwent jejunal-ileal bypass (Lazzarotto procedure) from year 2002 to 2014. Twenty-one patients were operated to reverse Lazzarotto procedure, of which nineteen underwent laparoscopic reversal $(n=19(90.47 \%))$, and two were converted to open $\mathrm{n}=2(9.52 \%)$. Laparoscopic procedures were either reversal of Lazzarotto and Souza procedure only ( $\mathrm{n}=9(42.9 \%))$, reversal of Lazzarotto and Souza procedure and sleeve gastrectomy ( $\mathrm{n}=$ $5(23.8 \%))$, reversal of Lazzarotto and Souza procedure and RYGB $(n=4(19.0 \%))$, and sleeve gastrectomy only $(\mathrm{n}=3(14.3 \%))$. The type of reversal procedure was dependent on the clinical presentation post-Lazzarotto and Souza procedure. All patients were followed up for weight 
loss, nutritional status and complications.

\section{Statistical methods}

Data was extracted and exported to SPSS Inc, IBM Version 26. Quantitative data was described using means and standard deviations and categorical variables were described using frequencies and percentages.

Results

Table 1: Baseline patient characteristics.

\begin{tabular}{|c|c|}
\hline Characteristics & Total \\
\hline $\mathrm{N}$ & 21 \\
\hline Age (years) & $40.6( \pm 9.5)$ \\
Mean & $29-70$ \\
Range & $5(23.8 \%)$ \\
\hline Gender & $16(76.2 \%)$ \\
Male & $110.4( \pm 9.5)$ \\
Female & $88.0( \pm 27.1)$ \\
\hline Weight (kg) & $41.7( \pm 4.6)$ \\
Initial & $33.4( \pm 6.7)$ \\
Pre-operative, prior to revision surgery & \\
\hline BMI (kg/m $\left.{ }^{2}\right)$ & $75.5( \pm 12.5)$ \\
Initial & $43-93$ \\
Pre-operative, prior to revision surgery & \\
\hline Maximum weight loss prior to revision surgery & (kg) \\
Mean & Range \\
\hline
\end{tabular}

A total of 21 patients required revisional surgery after their initial Lazzarotto and Souza procedure. The mean age for those patients was $41( \pm 9.5$ standard deviation (SD)) and $76.2 \%$ of them were female. The mean weight for these patients prior to their initial Lazzarotto and Souza procedure was $110 \mathrm{~kg}( \pm 9.5 \mathrm{SD})$ and the mean BMI was $41.7( \pm 4.6 \mathrm{SD})$. Just prior to having a revision of their initial Lazzarotto and Souza procedure, their mean weight was $88.0 \mathrm{~kg}( \pm 27.1 \mathrm{SD})$ and their mean BMI was 33.4( $\pm 6.7 \mathrm{SD})$. The maximum weight loss these patients experienced prior to their revisional surgery, was a mean total of $75.5 \mathrm{~kg}$ (Table 1 ). A total of $81.0 \%$ of the patients who were scheduled to undergo a revisional procedure were experiencing mechanical, nutritional, or metabolic complications at the time. The most common complication these patients were experiencing were diarrhea (61.9\%), excessive flatulence $(52.4 \%)$ and malnutrition (33.3\%). The most common nutritional deficiencies were deficiencies of vitamin D (23.8\%), ferritin (19.0\%) and vitamin B12 (14.3\%) (Table 2).

In terms of the type of revisional procedure that these patients underwent, $42.9 \%$ underwent a reversal of their Lazzarotto and Souza procedure only, 23.8\% underwent a reversal of their Lazzarotto procedure combined with a sleeve gastrectomy, 19\% underwent a reversal of their Lazzarotto procedure combined with a RYBG and $14.3 \%$ underwent sleeve gastrectomy only. The mean number of years between patients' original Lazzaratto and Souza procedure and revision of their initial procedure was 8.2 years
$( \pm 4.1 \mathrm{SD})$. Of 21 patients, 5 experienced complications after their revisional procedure $(23.8 \%)$, these complications consisted of: incisional hernia formation, weight regain, post-operative bleeding and hematoma formation and stenosis at the clipping site. Overall, the total change in BMI between patients' initial weight prior to the Lazzarotto and Souza procedure and after revision of their initial procedure was $12.7( \pm 4.3 \mathrm{SD})$ (Table 3$)$.

Table 2: Complications preceding revisional surgery.

\begin{tabular}{|c|c|}
\hline Complication & $\mathrm{N}(\%)$ \\
\hline Diarrhoea & $13(61.9 \%)$ \\
\hline Excessive flatulence & $11(52.4 \%)$ \\
\hline Malnutrition & $7(33.3 \%)$ \\
\hline Ferritin Deficiency & $4(19.0 \%)$ \\
\hline Vitamin D Deficiency & $5(23.8 \%)$ \\
\hline Vitamin B12 Deficiency & $3(14.3 \%)$ \\
\hline Hypoalbuminemia & $2(9.5 \%)$ \\
\hline Hypocalcaemia & $1(4.8 \%)$ \\
\hline Peripheral Edema/Ascites & $2(9.5 \%)$ \\
\hline Ring Invagination/Ring Bezoar & $1(4.8 \%)$ \\
\hline Elevated liver enzymes & $1(4.8 \%)$ \\
\hline Weight re-gain & $1(4.8 \%)$ \\
\hline Elevated tumour markers & $1(4.8 \%)$ \\
\hline None & $4(19.0 \%)$ \\
\hline
\end{tabular}

Table 3: Revisional surgery.

\begin{tabular}{|c|c|}
\hline Type and outcomes & $\mathbf{N}$ \\
\hline \multirow{2}{*}{$\begin{array}{c}\text { Type of revision } \\
\text { Reversal of Lazzarotto and Souza procedure } \\
\text { only }\end{array}$} & \\
\hline & $9(42.9 \%)$ \\
\hline \multirow{2}{*}{$\begin{array}{c}\text { Reversal of Lazzarotto and Souza procedure + } \\
\text { sleeve gastrectomy }\end{array}$} & $5(23.8 \%)$ \\
\hline & $4(19.0 \%)$ \\
\hline $\begin{array}{l}\text { Reversal of Lazzarotto and Souza procedure + } \\
\text { RYGB }\end{array}$ & $3(14.3 \%)$ \\
\hline \multicolumn{2}{|l|}{ Sleeve gastrectomy only } \\
\hline $\begin{array}{c}\text { Number of years between initial procedure and } \\
\text { revisional procedure (years) }\end{array}$ & $8.2( \pm 4.1)$ \\
\hline Mean & $2-17$ \\
\hline Range & \\
\hline Complications after revision surgery & $5(23.8 \%)$ \\
\hline $\begin{array}{l}\text { Weight }(\mathrm{kg}) \\
\text { Last follow-up after revision surgery }\end{array}$ & $79.9( \pm 13.4)$ \\
\hline $\begin{array}{l}\qquad \mathrm{BMI}\left(\mathrm{kg} / \mathrm{m}^{2}\right) \\
\text { Last follow-up after revision surgery }\end{array}$ & $29.2( \pm 3.6)$ \\
\hline $\begin{array}{l}\text { Total change in BMI (difference between initial } \\
\text { BMI and BMI on last follow-up) }\left(\mathrm{kg} / \mathrm{m}^{2}\right)\end{array}$ & $12.7( \pm 4.3)$ \\
\hline
\end{tabular}

\section{Discussion}

Lazzarotto and Souza procedure is a kind of jejunoileal bypass (JIB) with a constricting elastic ring placed just beyond the anastomosis in the jejunal limb. In the Lazzarotto and Souza procedure, $40 \mathrm{~cm}$ from the duodenojejunal flexure, the jejunum is anastomosed to the ileum $60 \mathrm{~cm}$ proximal to the ileocecal valve. 
A silastic ring is placed at the remnant jejunum to allow minimal amount of food content to enter the bypassed part of the small bowel thus preventing stasis and bacterial overgrowth. JIB was performed in the 1950s-1970s as a bariatric procedure to treat morbid obesity. The procedure was replaced by Roux-En-Y gastric bypass in the early 1980s as it was associated with more serious short and longterm complications [3]. Post jejunoileal bypass complications can be categorized into malabsorptive complications, and bacterial overgrowth complications in the excluded part of the small bowel [4]. Liver failure in the most serious complication and death was reported in 91 cases following IJB [5]. Other complications include severe electrolyte imbalance, diarrhea and excessive flatulence, renal stones formation, cholelithiasis, osteomalacia, vitamin deficiencies [6,7].

Despite being a modified JIP surgery, Lazzarotto and Souza procedure is associated with almost the same complications as the standard JIP surgery. Moreover, the presence of the plastic ring in the abdominal cavity makes revisional surgeries more challenging as it is associated with more adhesions, and some cases have formed phlegmon around the anastomosis. In our study, patients were categorized according to Lazzarotto and Souza procedure post-operative complications thus providing the most appropriate revisional surgery. We have noticed that the majority of patients present with diarrhea, with or without associated complications such weight regain and excessive flatulence. A minority of patients presented with malnutrition, vitamins deficiency and deranged liver enzymes.

Patients who presented with diarrhea and excessive flatulence, with or without malnourishment were successfully treated with the revision of the Lazzarotto and Souza procedure only, in which the jejunoileal anastomosis is taken down and the silastic ring divided and removed (Figures 1-4). Patients who presented with weight regain only, were successfully treated with laparoscopic sleeve gastrectomy alone and without the need to revise the Lazzarotto and Souza anastomosis. Patients who presented with weight regain, diarrhea and excessive flatulence were successfully treated with either laparoscopic sleeve gastrectomy with revision of the lazzarroto and Souza procedure or laparoscopic revision of Lazzarotto an Souza procedure with RYGB depending on eating habits of the patient and the presence of gastroesophageal reflux disease (GERD). A rare case included in this study is a 66-yearold female who underwent the Lazzarotto and Souza procedure and presented with weight loss anemia and fatigue. A thorough workup was done for this patient to rule out cancer first. Her blood tests showed anemia and elevated levels of CEA and C19.9. All other laboratory and radiological investigations were normal. The patient underwent a revision of Lazzarotto and Souza procedure with resection and reconstruction of the previous jejunoileal anastomosis and removal of the constrictive elastic ring. The postoperative period was uneventful. Three months after the revisional procedure, tumor markers normalized. The histopathology of the resected specimen came out negative for malignancy.

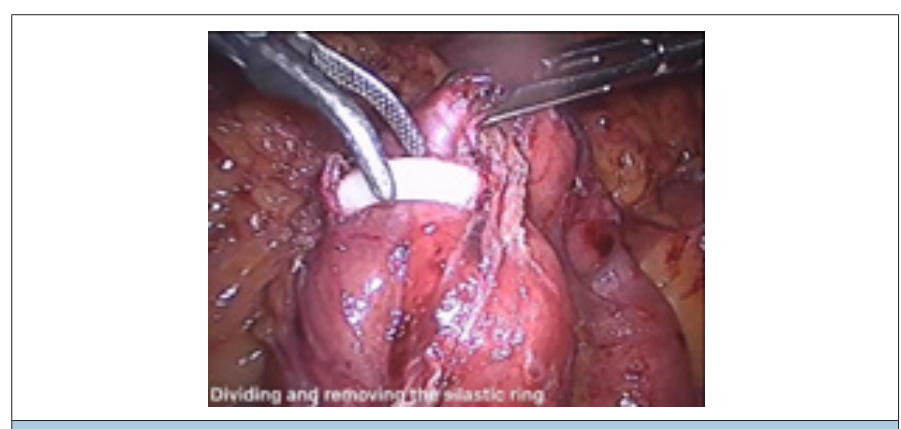

Figure 1: Revision of Lazzarotto and Souza procedure.

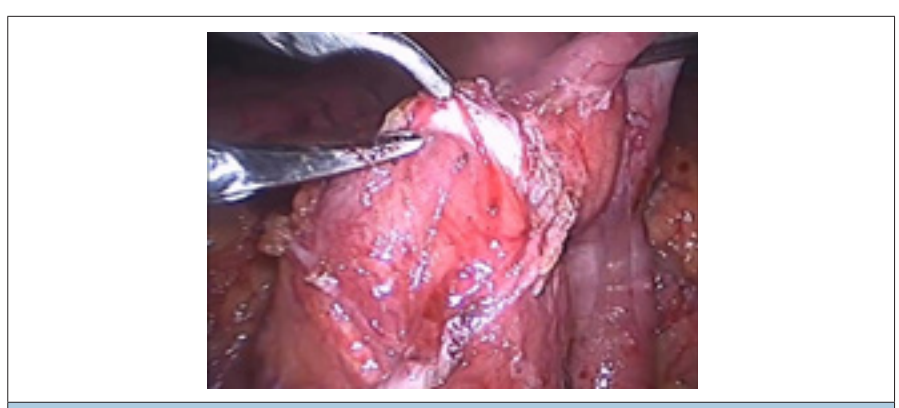

Figure 2: Revision of Lazzarotto and Souza procedure.

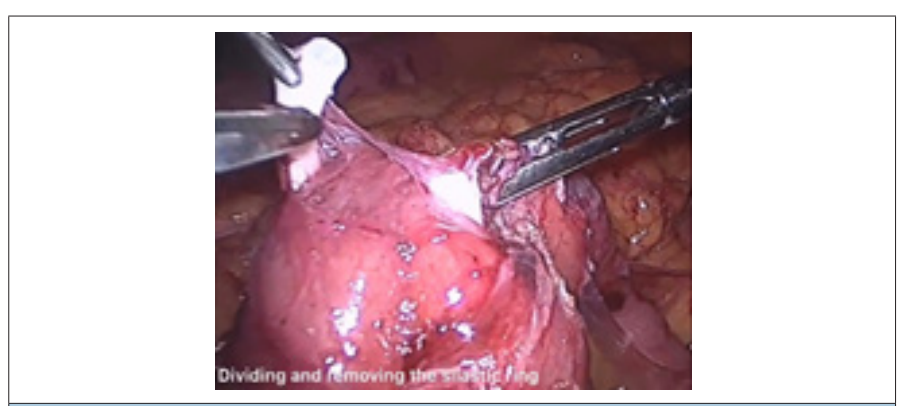

Figure 3: Revision of Lazzarotto and Souza procedure.

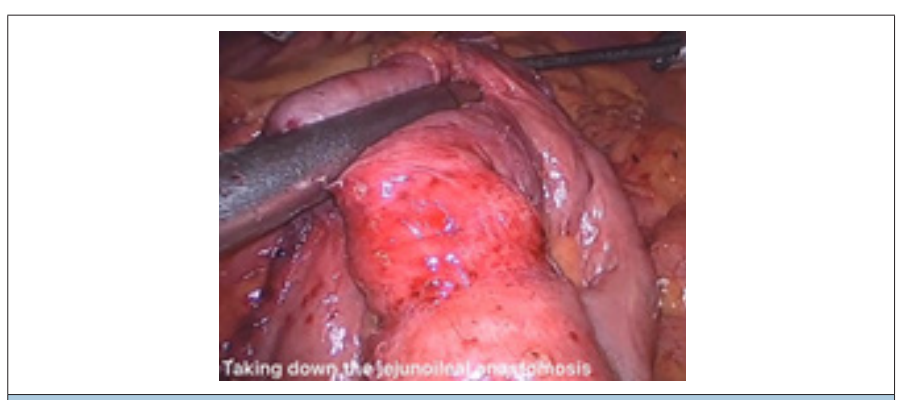

Figure 4: Revision of Lazzarotto and Souza procedure.

\section{Conclusion}

The Lazzarotto and Souza procedure is a non-approved effective surgery for weight reduction, however, it is associated with more post-operative complications compared with the standard bariatric procedure like RYGB and sleeve gastrectomy. The type of revisional surgery and management of the Lazzarotto and Souza procedure post-operative complications depend mainly on the patient's presentation. Therefore, proper history, clinical examination and investigation are required to categorize the patients for the most efficient revisional surgery they require. 


\section{References}

1. Haslam DW, James WP (2005) Obesity. Lancet 366(9492): 1197-1209.

2. Pi-Sunyer FX (1999) Comorbidities of overweight and obesity: Current evidence and research issues. Med Sci Sports Exerc 31(11 Suppl): S602-S608.

3. Buckwalter JA (1980) Clinical trials of jejunoileal and gastric bypass for treatment of morbid obesity. Am Surg 46(7): 377-381.

4. Drenick EJ, Ameut ME (1977) Bypass enteropathy an inflammatory process in the excluded segment with systemic complications. Am J Clin Nutr 30(1): 76-89.
5. Griffen WO Jr, Bivins BA, Bell RM (1983) The decline and fall of the jejunoileal bypass. Surg Gynecol Obstet 157(4): 301-310.

6. Holzbach RT (1977) Hepatic effects of jejunoileal bypass for morbid obesity. Am J Clin Nutr 30(1): 43-521.

7. Mole DR, Tomson CR, Mortensen N, Winearls CG (2001) Renal complications of jejunoileal bypass for obesity 94(2): 69-77.

For possible submissions Click below: 